\title{
Sitting pretty, but simmering with anger
}

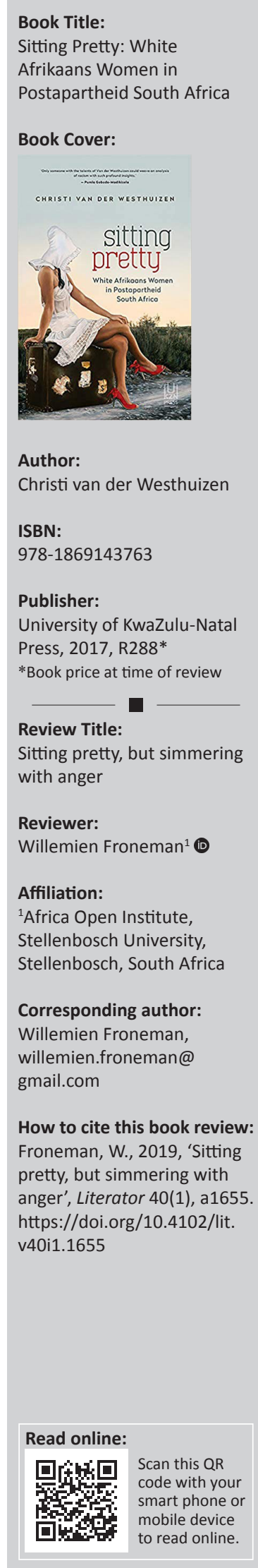

At the time of writing, there was an intense debate at Stellenbosch University about a nowretracted research article claiming that low education levels and unhealthy lifestyle behaviours contribute to an increased risk of lower cognitive functioning in South African coloured women. As I read some of the responses to the article, and sat through colloquia and seminars that highlighted - above all else - the inadequacy of our best efforts to deal with matters of race, I wondered where these debates left Sitting pretty - a book that seeks to understand how white Afrikaans women have responded to the challenges of post-apartheid democratisation (Van der Westhuizen 2017:3). What happens when we generalise along racial lines? Can we find a nuanced language to talk about something as unnuanced as racial thinking? How do we as scholars in the humanities and the social sciences rid ourselves of apartheid's ingrained classificatory systems when the world around us - the world that we study - still bear traces of that classificatory systems and organises itself around them in disturbing ways?

Christi van der Westhuizen approaches her subjects - post-apartheid white Afrikaans women without mollycoddling. Through focus groups with 25 participants and 6 follow-up in-depth interviews, she finds that they 'are engaged in one project above all: to become ordentlik, or respectable again'. The reason for their obsession with ordentlikheid, so she argues, is that 'they seek to rescue their identities from the moral abyss that apartheid and its official ending tipped them into, and to re-infuse their selves with moral worth' (Van der Westhuizen 2017:4). For this purpose, they latch on to that old discursive stereotype of Afrikaner heterofemininity, the volksmoeder ideal, 'refurbishing' it with a materialistic gospel of self-care, self-sacrifice, white privilege and colourblindness.

Her analysis of Sarie magazine's 'technologies of heterofemininity' gives content to current understandings of this ideal of white womanhood. Van der Westhuizen writes compellingly about the discursive acrobatics Sarie magazine employs to erase political history and how its anodyne narratives of beauty, self and family recruit readers to a reworked volksmoeder ideology. The strategies the magazine uses to reframe outdated and paternalistic ideas on feminine respectability around post-feminist choice and neoliberal self-actualisation make for disturbing reading.

The extent to which white Afrikaans women are 'interpellated' into this subject position is, to my mind, a different question. Van der Westhuizen (2017:67) hitches her argument to Sarie's circulation figures, arguing that it is 'the foremost example of culturally sanctioned knowledge aimed at individuals who occupy the subject position under review in this book', but this figure has plummeted from 132646 units at the time of her research to only 65849 in 2019. The mass media evidently interpellates white women into some kind of subject position, but perhaps Facebook, Pinterest and the local Community Protection Forum WhatsApp group are more influential in this regard than a print magazine that has lost more than half of its circulation in the past decade.

Another part of the problem is that Van der Westhuizen uses ordentlikheid and volksmoeder as both normative and analytical concepts. In other words, these concepts serve at once as signs of the white post-apartheid hegemonic femininity that is the focus of the book and as the tools to probe this subject position in the lived discourses of contemporary white Afrikaans women. On the upside, this approach allows for the hegemonic ideal-type by which Sitting pretty argues that white Afrikaans women orientate themselves to emerge. On the downside, it creates a methodological feedback loop that locks white Afrikaans women in a heteronormative apartheid narrative out of which there is little chance of escape. Van der Westhuizen's white Afrikaans woman is of a very particular type: for the most part, not one discomfited by the term 'Afrikaner'; not a lesbian; not a city dweller, a rural bohemian, a small-town bank clerk. She is not someone like Yolandi Visser, although Van der Westhuizen (2017:31) makes her pass for an 'Afrikaner

Copyright: (C) 2019. The Authors. Licensee: AOSIS. This work is licensed under the Creative Commons Attribution License. 
female'. It is only right towards the end of the book - in Chapter 5 - that the concept of 'neo-nationalist enclaves' emerges for the first time. This is a crucial piece of the puzzle Van der Westhuizen seeks to assemble because it contextualises and relativises the discursive and geographic positioning of the white Afrikaans woman that interests her within the broader South African political landscape. Van der Westhuizen's (2017:181) white Afrikaans woman prefers to live in a virtual white world like Durbanville or Centurion. Her middle-classness is the most distinctive thing about her.

This is not to detract from how fascinating and often harrowing Van der Westhuizen's material is. Here is documented that revolting white practice of referring to black people as 'die Groenewalds' (Van der Westhuizen 2017:184). The literal translation of Afrikaans phrases such as 'don't worry, Mommy' or 'hold yourself in' (Van der Westhuizen 2017:163) increases Sitting pretty's cringe factor. And yet, many of the interview transcriptions are surprisingly resistant to Van der Westhuizen's interpretation. In Chapter 4, for example, Van der Westhuizen argues that post-apartheid women's adherence to volksmoeder principles sustains a set of patriarchal notions of manhood, constituting them 'from the outside' as it were. With few exceptions, however, the interviewees talk in the past tense and in disparaging rather than celebratory terms about their mothers' position in a patriarchal system or their childhood relationship with their fathers. It is difficult to gauge whether these patterns also rule their current relationships or manifest in the ways they raise their sons. Van der Westhuizen (2017:174) is surprised that the discursive possibilities for "Afrikaner" men emanating from female subjects in this book do not include dissident subject positions'. But then again, she did not look in places where such discursive possibilities could exist. She maintains that 'respectability is the glue that holds the identity together as it adapts to changing historical conditions' and that this 'rule is sometimes exposed in the resistance to it' (Van der Westhuizen 2017:150). But I am not so sure. More than 'silence', 'service', and that unappetising-sounding notion of 'white sex', what stands out is these women's simmering anger. Their desire is to break free.
Indeed, the interviewees frequently admitted to things that can hardly be described as ordentlik: one confessed that she would rather see her father die than having to take care of him; another stated that she wants to say 'I hate children' (p. 123) and that it must be 'soul-destroyingly boring' to raise three of them at home (p. 134). A third one spoke candidly about her racist responses towards her own adopted, coloured child (p. 145). Often these women's associations with the idea of the volksmoeder are critical if not nonexistent, or better explained not in a stark sociological language of race and class by which the interviewees are repeatedly reined back in, but in the more humanising language of affect. Take the following excerpt as an example:

Nerina: We played [...] with the black children and I enjoyed it [...] My aunt said you're becoming black and then I [called out], 'I don't want to be black' [...] it was the first time that I thought I feel superior towards the black child [...] I was white and I believed it was better than being black.

Researcher: What is that 'better'?

Nerina: It was more civilized probably because their houses were poorer and dirtier than ours. (p. 32)

Researcher: I'm hearing a resonance with class. (p. 38)

As the book progresses, the sure-footed and declarative assertions of the introduction and early chapters indeed make way for complexities and nuance that do not fit so neatly into Sitting pretty's stated theoretical schema. These come to the fore in the illuminating discussion on affect and shame with which Van der Westhuizen ends the book. She shows the transformative power of acknowledged shame and, conversely, the destructive cycles of anger triggered when shame goes unacknowledged. How different the above interview and the argument as a whole would have looked if the focus were less on outing these women as adherents to a hegemonic cult of ordentlikheid and more on understanding - perhaps even with some pathos - their unacknowledged shame.

\section{References}

Van der Westhuizen, C., 2017, Sitting pretty: White Afrikaans women in postapartheid South Africa, University of KwaZulu-Natal Press, Pietermaritzburg. 